\title{
Analysis of development grinding wheels on the basis of microcrystalline corundum
}

Prof. Eng. Karel Kocman, Sc.D.

Institute of Production Engineering, Faculty of Technology, Tomáš Bat’a University in Zlín

Grinding is a finishing operation featuring high precision, correct geometrical form and usually a very good surface quality. One of the factors necessary to achieve needed values is a correct choice and quality of the grinding wheel. The development of new technologies in the field of finishing functional surfaces has been focused on the production of new advanced grinding materials ensuring higher efficiency and reduction of the temperature of contact between the ground surface and the grinding wheel. The desired result is enhanced quality of the ground surfaces. One of the feasible ways of giving a solution to the problem is the application of highly porous grinding materials, sintered corundums. The presented article is focused on the analysis of development grinding wheels containing microcrystalline corundum.

Keywords: Prediction, thermodynamic effects, thermal balance, grinding, Flir 2000

\section{References}

[1] HOLEŠOVSKÝ, F., NOVÁK, M., MICHNA, Š.: Studium změn broušené povrchové vrstvy při dynamickém zatěžování. In Strojírenská technologie. FVTM UJEP : Ústí n. Labem. 2007. str. 73 - 77. ISSN 1211-4162.

[2] HOLEŠOVSKÝ, F., NOVÁK, M. Analýza a výsledky měření technologických charakteristik brousících procesů. Zpráva FVTM UJEP v Ústí nad Labem, listopad 2009.

[3] KOCMAN, K.: Problemȳ okhranȳ okruzhayushchey sredȳ, svyazannȳe s vȳsokoskorostnȳm rezaniyem. In: Mezhdunarodnaya nauchnaya konferencia "Edinnoye obrazovatelnoye prostranstvo slavyanskich gosudarstv v XXI veke: problemȳ i perspektivȳ” Russiya, Bryansk, State Technical University, 2-4. 4. 2002, s. 88 - 92 . ISBN 589838-55-8

[4] KOCMAN, K.: Speciální technologie - obrábění. CERM, leden 2004, s.227. ISBN 80-214-2562-8

[5] KOCMAN,K. - PATA.V.: Prediction of thermodynamic effects in grinding and methods of their quantification. In. Strojírenská technologie, ročník X, č.3. FVTM UJEP : Ústí n. Labem. 2005. s.96 - 121. ISSN 1211-4162.

[6] MÁDL, J. - RÁZEK,V. - KOUTNÝ, V.: Vlastnosti povrchu po tvrdém obrábění. In Strojírenská technologie. roč. XIII., č.4. FVTM UJEP : Ústí n. Labem. 2008. s.20 - 24. ISSN 1211 - 4162

Reviews:

Prof. Jan Mádl, MSc., Ph.D. Prof. František Holešovský, MSc., Ph.D. 